$\underline{\text { Tajdid: Jurnal Pemikiran Keislaman dan Kemanusiaan }}$

Vol. 2 No. 2 Oktober 2018

\title{
KONSEP PENDIDIKAN AKHLAK DALAM KITAB KITAB AHLAKUL LIL BANIN KARYA UMAR IBNU AHMAD BARJAH
}

\author{
Muhamad Arif \\ Sekolah Tinggi Agama Islam (STAI) Alazhar Menganti Gresik \\ Muhamadarif0705@gmail.com
}

\begin{abstract}
Abstrak
Umar Ibnu Ahmad Barjah adalah seorang yang mempunyai Kepandaiannya dalam karya tulis, beliau menguasai bahasa Arab dan sastranya, ilmu tafsir dan Hadits, ilmu fiqih dan tasawuf, ilmu sirah dan tarikh. Ditambah, penguasaan bahasa Belanda dan bahasa Inggris. Salah satu karya besar beliau adalah kitab akhlakul lil banin, secara khusus menyoroti tentang pendidikan akhlak kepada anak, kitab yang sering di jadikan rujukan pada dunia pendidikan terutama dunia pondok pesantren. Berawal dari inilah peneliti melakukan penelitian ribrary research dari kitab akhlakul lil banin dengan menggunakan teknik analisis data, content analisis yang terdiri dari reduksi data, coding, inductive and deductive approaches to coding in qualitative content analysis. Yang mendapatkan kesimpulan tentang pendidikan akhlak perspektif Umar Ibnu Ahmad Barjah dalam kitabnya akhlakul lil banin, yaitu: Pendidikan akhlak menjadi hal yang wajib ditanamkan kepada anak sejak kecil, di mulai dari pendidikan Akhlak kepada Allah, Akhlak kepada Nabi Muhammad SAW, Akhlak kepada kedua orang tua, Akhlak kepada saudara, Akhlak kepada tetangga, Akhlak kepada guru.
\end{abstract}

Kata Kunci: Pendidikan, Akhlak, Umar Ibnu Ahmad Barjah.

PENDAHULUAN

$\mathrm{P}$ emahaman terhadap konsep pendidikan terdiri dari dua aktifitas utama, pertama yaitu pendidikan sebagai tindakan manusia sebagai usaha membimbing manusia yang lain (educational practice), dan kedua pendidik sebagai ilmu pendidikan (educational though). Meminjam pengetian dari Gununing yang menjelaskan tentang perbedaan dari kedua isltilah di atas yaitu, pedagogie untuk pendidikan dalam arti praktik dan pedagogiek untuk ilmu dari pendidikan yang berhubungan dengan teori pendidikan. ${ }^{1}$ Pendidikan mempunyai banyak pengertian menurut para pakar. Poerwada dalam Abudin Nata menjelaskan bahwa pendidikan

\footnotetext{
${ }^{1}$ Departemen Pendidikan dan Kebudayaan, Dampak Moderenisasi Terhadap Hubungan Kekerabatan di Daerah Jawa Tengah. (Jawa Tengah: Departemen Pendidikan), 27.
} 
adalah sebuah cara perbuatan dan sebagainya, mengajar atau mengajarkan serta memberikan pengetahuan atau pelajaran. Abdurrahman an nahlawi lebih cenderung mengartikan pendidikan dengan kata tarbiyah, yang berasal dari tiga sumber kata, yang pertama adalah rabba yarbu yang mempunyai arti tambah atau tumbuh, karena pendidikan adalah misi untuk menambah bekal pengetahuan pada anak, dan yang kedua adalah berasal dari kata rabiya yarba yang mempunyai arti besar, karena pendidikan mempunyai arti membesarkan jiwa seseorang untuk memperluas wawasan anak. Dan yang ketiga adalah dari kata, rabba yarubbu, yang berarti memperbaiki, menguasai urusan, menuntun, menjaga, dan memelihara. ${ }^{2}$

Senada dengan hal tersebut Amos Naeloka dan Grace menjelaskan pendidikan adalah proses upaya meningkatkan nilai peradaban individu atau masyarakat dari suatu keadaan yang lebih baik. ${ }^{3}$ Menurut Ki Hajar Dewantara dalam Sugiono mengemukakan tentang pengertian pendidikan yaitu, daya dan upaya untuk memajukan perkembangan budi pekerti (kekuatan batin) pikiran (intelek) dan jasmani dari seorang anak. Maka upaya untuk memajukan anak adalah menyikapi subyek didik sebagai pribadi yang potensial serta nantinya mampu berdiri dan maju atas kekuatannya. ${ }^{4}$ Lebih lanjut, M. Arifin menjelaskan tentang pendidikan islam adalah suatu usaha orang dewasa muslim yang bertaqwa secara sadar mengarah dan membimbing pertumbuhan dan perkembangan fitrah (kemampuan dasar) anak didik melalui aturan Islam kearah titik maksimal pertumbuhan dan perkembangan. ${ }^{5}$

Keberadan Pendidikan dalam masyarakat mempunyai peran yang sangat penting, para ahli dalam mendefinisakan pendidikan mempunyai banyak pandangan, terkadang tidak saja pada sisi redaksi bahkan pada sisi substansi. Pendidikan kepribadian memiliki peran besar pada peradaban manusia, di dalam membangun suatu budaya. Terutama keberadaan peran dari pendidikan akhlak, dikarenakan pada dewasa ini memajukan peradaban dan kebudayaan adalah berupa penghiasan jiwa individu dalam wujud kebaikan. ${ }^{6}$ Karena dengan melewati proses pendidikan di harapkan anak-anak akan di matangkan untuk bisa menjadi anggota masyarakat yang baik dan potensial, hal ini merupakan sebuah tanda bahwa generasi

\footnotetext{
${ }^{2}$ Abudin Nata, Filsafat Pendidikan Islam (Jakarta: Gaya Media Pratama. 2005), 9.

${ }^{3}$ Amos Neolaka dan Grace Amialia, Landasan Pendidikan Dasar Diri Sendiri Menuju Perubahan Hidup (Depok: Kencana, 2017), 14.

${ }^{4}$ Sugiono, dkk., Pengantar Ilmu Pendidikan (Surabaya: Penerbit Bintang, 2010), 34-35.

${ }^{5}$ M. Arifin, Ilmu Pendidikan Islam Suatu Tinjauan Teoritis dan Praktis Berdasarkan Pendidikan Interdisipliner (Jakarta: PT. Bumi Aksara. 1991), 31.

${ }^{6}$ Pascasarjana UIN Sunan Ampel, Antologi Kajian Islam, Seri 27. (Surabaya: PASCA UINSA. 2016), 60.
} 
sudah siap untuk menggantikan generasi sebelumnya. ${ }^{7}$ Generasi muda menjadi penerus yang mempunyai kewajiban dalam meningkatkan SDM serta kemampuan, keterampilan dan keuletannya dan tak lupa tentang penerus generasi yang berakhlak mulia. Meminjam pernyataan dari Syaikh Utsaimin tentang akhlak yang mulia adalah akhlak yang dapat membuat hati pelakunya merasa tenang, lapang dan tentram serta pergaulannya baik. Rasulullah bersabda:

"Sesungguhnya kebaikan adalah akhlak yang baik:"apabila seorang mempunyai akhlak yang baik kepada Allah dan manusia, ia akan memperoleh kebaikan yang banyak, dadanya lapang terhadap Islam, hatinya menjadi tenang dengan iman dan dia akan bergaul dengan manusia dengan akhlak yang baik. ${ }^{8}$

Menurut Tardib, hal di atas sejalan dengan misi yang di bawa oleh Rasulullah SAW, menyampaikan ajaran Islam yaitu, menyempurnakan akhlak manusia, beliau bersabda "aku diutus untuk menyempurnakan akhlak manusia" (HR. Ahmad dan Baihaqi). ${ }^{9}$ Sejalan dengan hadis di atas, Imam Baqir dalam Sultani dan Ghulam mengatakan, tentang seorang yang baik adalah yang paling sempurna dari sudut pandang iman adalah akhlaknya, begitu juga imam Shadiq mengatakan "orang mukmin pada hari kiamat tidak membawa kehadapan Allah yang lebih disukai, kecuali akhlak yang bai dengan manusia, selain tugas-tugas yang diwajibkannya". ${ }^{10}$ Pandangan senada juga dikemukan oleh Ali Abdul Halim, yang menjelaskan bahwasanya pengertian akhlak sendiri, menunjukkan sejumlah sifat tabiat fitri (asli) yang berada pada diri manusia, fitrah manusia mempunyai dua bentuk, pertama yaitu sifat bathiniyah (kejiwaan) dan yang kedua adalah sifat dhahiriyah (kejiwaan). ${ }^{11}$

Menegaskan hal tersebut, Abu Nasir dalam salah satu karyanya yang dikemukakan Rod Lajih berkata: "kebahagiaan sepenuhnya ada pada akhlak mulia, sebagaimana penyempurnaan pohon adalah buah. Maka bahagialah orang yang ilmunya menjadi perantara bagi penyucian akhlak. ${ }^{12}$ Peran akhlak memang tak tergantikan dari berbagai lapisan, dari mulai lapisan masyarakat, pendidikan dan individual seseorang. Dalam konteks inilah, memberikan indikasi kepada peneliti tentang peran penting dari pendidikan akhlak, peneliti ingin menelaah lebih detail,

\footnotetext{
${ }^{7}$ Sugiono, dkk., Pengantar Ilmu Pendidikan, ...60.

${ }^{8}$ Muhbib Abdul Wahab, Selalu Ada Jawaban (Jakarta Selatan: Agromedia Pustaka, 2013), 90.

${ }^{9}$ Tardib, "Pendidikan Karakter dalam Islam Pemikiran Imam Al-Ghazali tentang Pendidikan Karakter Anak Berbasis Akhlak al-karimah" (Vol 03. No.02 Desember, 2017), 197-215.

${ }^{10}$ Sultani dan Ghulam, Hal yang bersih kunci ketenangan Jiwa (Jakarta: Zahra Publising, 2006), 195.

${ }^{11}$ Ali Abdul Halim, Ma'a al-Aqidah wa al-harakah wa al-manhaj fi Khairi Ummatin Ukhrijat li An-Nas (Jakarta: Gema Insan Press, 1992)

${ }^{12}$ Rod Lajih, Dalam Buaian Nabi Merajut Kebahagiaan Si Kecil (Jakarta: Zahra. 2005), 148.
} 
tentang sebuah pendidikan akhlak perspektif Umar Ibnu Ahmad Barjah dalam kitab karangan Umar Ibnu Ahmad Barjah yang berjudul akhlakul lil banin. Sebuah kitab kecil namun kaya dengan konsep mendidik anak utamanya pada sisi akhlak dan kitab juga menjadi pedoman awal dan rujukan bagi para pelajar di dunia pondok pesantren.

\section{METODE PENELITIAN}

Metode penelitian ini menggunakan jenis penelitian library research yaitu mengumpulkan data atau karya tulis ilmiah yang bertujuan dengan objek penelitian atau pengumpulan data yang bersifat kepustakaan yang dilaksanakan untuk memecahkan suatu masalah yang pada dasarnya tertumpu pada penelaahan kritis dan mendalam terhadap bahan-bahan pustaka yang relevan. library research juga menjadi langka awal untuk menyiapkan kerangka penelitian guna memperoleh penelitian sejenis, memperdalam kajian teori atau mempertajam metodologi. ${ }^{13}$ Sumber data dalam penelitian ini yaitu sumber data primer dan sumber data sekunder. Sumber data primer adalah Akhlakul lil Banin karangan Umar Ibnuu Ahmad Barjah. Sumber data sekunder yang digunakan adalah sumber yang membahas tentang pendidikan akhlak baik berupa buku maupun tulisan para tokoh lain yang di dalamnya membahas persoalan akhlak. Selanjutnya, teknik analisa data dalam penelitian ini menggunakan sebuah pendekatan yang lebih fokus pada deskripsi dari pada pada pengembangan konseptual terdiri dari: (a) Reduksi data .(b) Coding. (c) Inductive and Deductive Approaches to Coding in Qualitative Content Analysis.

\section{HASIL PENELITIAN DAN PEMBAHASAN}

\section{Biografi Umar Ibnu Ahmad Barjah}

Hampir semua santri di pesantren pernah mempelajari buku-buku karya Syaikh Umar Baraja dari Surabaya. Sudah sekitar 11 judul buku yang diterbitkan, seperti Al-Akhlaq Lil Banin, kitab Al-Akhlaq Lil Banat, kitab Sullam Fiqih, kitab 17 Jauharah, dan kitab Ad'iyah Ramadhan. Semuanya terbit dalam bahasa Arab, sejak 1950 telah digunakan sebagai buku kurikulum di seluruh pondok pesantren di Indonesia. Secara tidak langsung Syaikh Umar Baradjah ikut mengukir akhlaq para santri di Indonesia. Buku-buku tersebut pernah di cetak Kairo, Mesir, pada 1969 atas biaya Syeikh Siraj Ka'ki, dermawan Mekkah, yang dibagikan secara cumacuma ke seluruh dunia Islam. Buku-buku bermanfaat luas, pada 1992 telah

\footnotetext{
${ }^{13}$ Mestika Zed, Metode Penelitian Kepustakaan (Jakarta: Yayasan Obor Indonesia, 2008),
} 1. 
diterbitkan ke dalam bahasa Indonesia, Jawa, Madura, dan Sunda. Selain menulis buku pelajaran, Syaikh Umar juga menulis syair-syairnya dalam bahasa Arab dengan sastranya yang tinggi. Menurut ustadz Ahmad bin Umar, karyanya cukup banyak dan belum sempat dibukukan. Selain itu, terdapat karya lain, seperti masalah keagamaan, yang masih bertuliskan tangan dan tersimpan rapi dalam perpustakaan keluarga. Kepandaiannya dalam karya tulis, disebabkan dia menguasai bahasa Arab dan sastranya, ilmu tafsir dan Hadits, ilmu fiqih dan tasawuf, ilmu sirah dan tarikh. Ditambah, penguasaan bahasa Belanda dan bahasa Inggris. ${ }^{14}$

\section{Guru Umar Ibnu Ahmad Barjah}

Guru-guru Syaikh Umar Baradja, antara lain, Al-Ustadz Abdul Qodir bin Ahmad bil Faqih (Malang), Al-Ustadz Muhammad bin Husein Ba'bud (Lawang), Al-Habib Abdul Qodir bin Hadi Assegaf, Al-Habib Muhammad bin Ahmad Assegaf (Surabaya), Al-Habib Alwi bin Abdullah Assegaf (Solo), Al-Habib Ahmad bin Alwi Al-Jufri (Pekalongan), Al-Habib Ali bin Husein Bin Syahab, Al-Habib Zein bin Abdullah Alkaf (Gresik), Al-Habib Ahmad bin Ghalib Al-Hamid (Surabaya), Al-Habib Alwi bin Muhammad Al-Muhdhar (Bondowoso), Al-Habib Abdullah bin Hasa Maulachela, Al-Habib Hamid bin Muhammad As-Sery(Malang), Syaikh Robaah Hassunah Al-Kholili (Palestina), Syaikh Muhammad Mursyid (Mesir)-keduanya tugas mengajar di Indonesia.

Selain menimba ilmu kepada para tuan guru/ulama di Indonmesia, Umar Ibnu Ahmad Barjah juga menutut ilmu kepada para Syaikh yang berada di luar negeri diantaranya, Al-Habib Alwi bin Abbas Al-Maliki, As-Sayyid Muhammad bin Amin Al- Quthbi, As-Syaikh Muhmmad Seif Nur, As-Syaikh Hasan Muhammad Al-Masysyath, Al-Habib Alwi bin Salim Alkaff, As- Syaikh Muhammad Said Al-Hadrawi Al-Makky (Mekkah), Al-Habib Muhammad bin Hady Assegaf (Seiwun, Hadramaut, Yaman), Al- Habib Abdullah bin Ahmad Al-Haddar, Al-Habib Hadi bin Ahmad Al-Haddar ('inat, Hadramaut, Yaman). Alhabib Abdullah bin Thahir Al-Haddad (Geidun, Hadaramaut, Yaman), Al-Habib Abdullah bin Umar Asy-Syatiri (Tarim, Hadramaut, Yaman), Al-Habib Hasan bin Ismail Bin Syeikh Abu Bakar ('inat, Hadramaut, Yaman), Al-Habib Ali bin Zein Al-Hadi, Al- Habib Alwi bin Abdullah Bin Syahab (Tarim, Hadramaut, Yaman), Al-Habib Abdullah bin Hamid Assegaf (Seiwun, Hadramaut, Yaman), AlHabib Muhammad bin Abdullah Al-Haddar (Al-Baidhaa, Yaman), Al-Habib Ali bin Zein Bilfagih (Abu Dhabi, Uni Emirat Arab), As- Syaikh Muhammad Bakhit Al-

\footnotetext{
${ }^{14}$ Muhammad Achmad Asseggaf, Sekelumit riwayat hidup Al-Ustadz Umar bin Achmad Baradja (Surabaya: Panitia Haul ke-V, 1995)
} 
Muthii'i (Mesir), SayyidiMuhammad Al-Fatih Al-Kattani (Faaz, Maroko). Sayyidi Muhammad Al-Munthashir Al-Kattani (Marakisy, Maroko), Al-Habib Alwi bin Thohir Al-Haddad (Johor, Malaysia), Syeikh Abdul 'Aliim As-Shiddiqi (India), Syaikh Hasanain Muhammad Makhluf (Mesir), Al-Habib Abdul Qodir bin Achmad Assegaf (Jeddah, Arab Saudi). ${ }^{15}$

\section{Kiprah Dakwah Umar Ibnu Ahmad Barjah}

Syaikh Umar mengawali kariernya mengajar di Madrasah Al-Khairiyah Surabaya tahun 1935-1945, yang berhasil menelurkan beberapa ulama dan asatidz yang telah menyebar ke berbagai pelosok tanah air. Di Jawa Timur antara lain, almarhum al-ustadz Achmad bin Hasan Assegaf, almarhum Al-Habib Umar bin Idrus Al-Masyhur, almarhum al-ustadz Achmad bin Ali Babgei, Al-habib Idrus bin Hud Assegaf, Al-habib Hasan bin Hasyim Al-Habsyi, Al-habib Hasan bin Abdul Qodir Assegaf, Al-Ustadz Ahmad Zaki Ghufron, dan Al- Ustadz Dja'far bin Agil Assegaf. Kemudian, dia pindah mengajar di Madrasah Al-Khairiyah, Bondowoso. Berlanjut mengajar di Madrasah Al-Husainiyah, Gresik tahun 19451947. Lalu mengajar di Rabithah Al-Alawiyyah, Solo, tahun 1947-1950. Mengajar di Al-Arabiyah Al-Islamiyah, Gresik tahun 1950-1951. Setelah itu, tahun 19511957, bersama Al-habib Zein bin Abdullah Al-kaff, memperluas serta membangun lahan baru, karena sempitnya gedung lama, sehingga terwujudlah gedung yayasan badan wakaf yang di beri nama Yayasan Perguruan Islam Malik Ibrahim.

Selain mengajar dilembaga pendidikan, Syaikh Umar juga mengajar di rumah pribadinya, pagi hari dan sore hari, serta majelis ta'lim atau pengajian rutin malam hari. Karena sempitnya tempat dan banyaknya murid, dia berusaha mengembangkan pendidikan itu dengan mendirikan Yayasan Perguruan Islam atas namanya, Al-Ustadz Umar Baradja. Ini sebagai perwujudan hasil pendidikan dan pengalamannya selama 50 tahun. Hingga kini masih berjalan, dibawah asuhan putranya, Al-Ustad Achmad bin Umar Baradja. Selain itu, amal ibadahnya meluas ke bidang lain, sehingga memerlukan dana yang cukup besar, dia juga menggalang dana untuk kebutuhan para janda, fakir miskin, dan yatim piatu khususnya para santrinya, agar mereka lebih berkonsentrasi dalam menimba ilmu.

Salah satu karya monumentanya adalah membangun Masjid Al-Khair (danakarya I-48/50, Surabaya) pada tahun 1971, bersama KH. Adnan Chamim, setelah mendapat petunjuk dari Al-Habib Sholeh bin Muhsin Al-Hamid (Tanggul) dan Al-habib Zein bin Abdullah Al-Kaff (Gresik). Masjid ini sekarang digunakan untuk berbagai kepentingan dakwah masyarakat Surabaya. Penamplan Syeikh

\footnotetext{
${ }^{15}$ Ibid.
} 
Umar sangat bersahaja, tetapi dihiasi sifat-sifat ketulusan niat yang disertai keikhlasan dalam segala amal perbuatan duniawi dan ukhrawi. Dia juga mejabarkan akhlaq ahlul bait, keluarga Nabi dan para sahabat, yang mencontoh baginda Nabi Muhammad SAW. Dia tidak suka membangga- banggakan diri, baik tentang ilmu, amal, maupun ibadah. Ini karena sifat tawadhu' dan rendah hatinya sangat tinggi. ${ }^{16}$

\section{Pendidikan Akhlak dalam Kitab Kitab Ahlakul Lil Banin}

Keberadaan akhlak sangatlah penting pada kehidupan di masyarakat, para filosof muslim menaruh akhlak menjadi yang teratas dalam hal yang harus di pelajar, meminjam pemaparan dari Abu Nasir Al-Farabi, yang menyatakan tentang akhlak adalah kesimpulan ilmu dan pengantar kebahagiaan, karena orang alim yang tidak berakhlak tidaklah mulia dan sempurna. ${ }^{17}$ Berawal dari seberapa pentingnya keberadaan akhlak, Umar Ibnu Ahmad Barjah, dalam kitab ahlakul lil banin. Memberi pandangan tentang pentingnya penanaman pendidikan akhlak yang harus dimulai dari kecil; "Umar Ibnu Ahmad Barjah, memberikan contoh tentang keberadaan ranting yang bengkok namun pohon sudah terlanjur besar dan rantingnya sudah tebal. Begitulah sebuah contoh dari seorang anak yang tidak berakhlak dari kecilnya, tidak mungkin ia berakhlak dikala dia telah besar. ${ }^{18}$

\section{Akhlak Kepada Allah SWT}

Akhlak terhadap Allah adalah segala prilaku yang dilakukan oleh seseorang yang ditujukan kepada Allah, karena akhlak ini adalah akhlak yang paling agung dan diwajibkan bagi umat manusia. Dalam pendidikan kepada anak harus menitikberatkan dalam hal ini, karena hanya kepada Allah SWT yang berhak disembah dan hanya kepada Allahlah rasa syukur dipanjatkan, karena hanya Allahlah yang maha pemberi nikmat, maha pencipta, maha pemberi rizki seta berhak menerima kedudukan dan kecintaan yang sempurna. ${ }^{19}$ Menurut, Umar Bin Achmad Baradja ${ }^{20}$ keberadaan Allah SWT yang telah menanamkan kasih sayang dalam hati ibu dan bapak hingga memelihara sampai sempurna dan ayah dan ibu menjadikan kamu mencintai gurumu hingga ia mengajarimu ilmu yang berguna bagimu dalam agama dan dunia serta banyak lagi kenikmatan Allah ta'ala bagimu yang tak terbilang. "dan jika kamu menghitung kenikmatan Allah SWT, niscaya kamu tak dapat menentukan jumlahnya" (An-Nahl/16: 18). Akhlak yang harus dilakukan kepada Allah, yaitu:

\footnotetext{
${ }^{16}$ Lihat Majalah Al Kisah No. 07/Tahun V/26 Maret, 8 April 2007.

${ }^{17}$ Rod Lajih, Dalam Buaian Nabi Merajut Kebahagiaan Si Kecil...148.

${ }^{18}$ Khoirul Zad Findy, Akhlakul lil Bani Jilid 1: Umar Ibnu Ahmad Barjah inilah akhlak yang mulia (Jakarta: Alfindy Press), 17.

${ }^{19}$ Adnan Hasan Haris Baharits, Mendidik Anak Laki-laki ( Jakarta: Gema Insani, 2007), 66.

${ }^{20}$ Umar Bin Achmad Baradja, Bimbingan Akhlak Jilid 2 (Jakarta: Pustaka Amani, 1337 $\mathrm{H} / 2016), 5$.
} 
a. Mengagungkan dan mencintai-Nya.

b. Mensyukuri semua nikmat yang diberikan-Nya.

c. Menjalankan semua perintah-Nya.

d. Menjauhi semua larangan-Nya.

e. Mengagungkan semua Malaikat-malaikat-Nya.

f. Mengagungkan semua Rasul-rasul-Nya.

g. Mengagungkan semua Nabi-nabi-Nya.

h. Mengagungkan orang-orang saleh dalam beribadah kepada-Nya.

i. Mencintai semuanya karena Allah juga mencintainya. ${ }^{21}$

\section{Akhlak Kepada Muhammad SAW}

Menjelaskan sejarah kehidupan Rasulullah dan segala peristiwa dalam dakwahnya kepada anak merupakan kewajiban orang tua. Anak harus dikenalkan dengan sejarah kehidupan Rasulullah SAW, sebelum mengenal kehidupan tokoh lainnya. Dan menjelaskan bahwa pengutusan Rasulullah adalah suatu karunia terbesar yang diberikan Allah kepada hambanya. ${ }^{22}$ Nabi Muhammad SAW adalah manusia terbaik akhlaknya. Allah ta'ala telah memujinya dengan firmanNya: "sesungguhnya engkau seorang yang memiliki budi pekerti yang agung". ${ }^{23}$ Allah SWT menjadikannya sebagai teladan bagi kaum muslimin dalam perkataan dan perbuatannya sebagaimana Allah ta'ala berfirman: "adalah bagi kamu dalam diri rasulullah terdapat teladan yang baik". ${ }^{24}$ Allah SWT telah mengutusnya untuk menyempurnakan adab dan akhlak. Dalam hadis: "aku di utus untuk menyempurnakan akhlak mulia". Dalam kitab akhlakul lil banin, di paparkan tentang akhlak yang harus kita lakukan kepada Nabi Muhammad SAW, yaitu:

a. Kewajiban untuk mencintaiNya dengan kecintaan yang sangat istimewa.

b. Mencintai kepada keluarga dan sahabat nabi Muhammad SAW.

c. Mentaati nabi Muhammad SAW dengan semua perintahNya, serta menjahui laranganNya. ${ }^{25}$

\section{Akhlak Kepada Ayah Dan Ibu}

Umar Ibnu Ahmad Barjah, dalam kitab ahlakul lil banin. Memberi pandangan tentang akhlak seorang anak terhadap ayah dan ibunya, yang telah mendidik penuh

${ }^{21}$ Khoirul Zad Findy, Akhlakul lil Bani Jilid 1: Umar Ibnu Ahmad Barjah inilah akhlak yang mulia,....19.

${ }^{22}$ Adnan Hasan Haris Baharits, Tangung Jawab Anak Terhadap Anak, Jakarta: Gema Insani, 1996), 10.

${ }^{23}$ Departemen Agama RI, Alqur'an Terjemahan dalam surah Al-Qalam/68: 4

${ }^{24}$ Departemen Agama RI, Alqur'an Terjemahan dalam surah Al-Ahzab/33: 21

${ }^{25}$ Umar Bin Achmad Baradja, Bimbingan Akhlak Jilid 2,...7. 
dengan perjuangan dan betapa besar rasa citanya. Dengan apa kamu bisa membalas? Sudah pasti kamu tidak bisa membalasnya, maka berakhlak adalah suatu balasan yang wajib di berikan terhadap mereka. Seperti:

a. Mematuhi perintahnya dengan penuh cinta dan penghormatan.

b. Berbuat apapun yang menimbulkan rasa bahagia di hatinya.

c. Selalu tersenyum dihadapannya.

d. Selalu mushafahah (bersalaman/cium tangan) setiap bertemu.

e. Selalu mendo'akannya supaya panjang umur serta dalam keselamatan dan kesehatan.

f. Jangan berbuat sesuatu yang menjadikan sakit hati.

g. Janganlah bermuka masam dihadapannya ketika diperintah.

h. Jangan pernah marah kepadanya.

i. Jangan pernah berbohong kepadanya.

j. Jangan pernah berkata kotor kepadanya.

$\mathrm{k}$. Jangan menatapnya dengan mata yang melotot.

1. Jangan pernah mengeraskan suara di atas suaranya ketika berbicara.

m. Jangan pernah meminta sesuatu dihadapan para tamu.

n. Jika Ibu mencegah, jangan pernah melawan, patuh dan diamlah.

o. Jangan pernah marah dan menangis dihadapannya.

p. Janganlah berdehem-dehem terhadapnya.

q. Selalu berbuat hal-hal yang menjadikan hati ayah dan ibu bahagia. ${ }^{26}$

\section{Akhlak Terhadap Saudara}

Keberadaan saudara pada diri manusia, menurut orang jawa, terbagi menjadi dua, pertama adalah (sedulur cedak) Atau bisa di sebut dengan saudara dekat dan (sedulur adoh) atau biasa disebut dengan saudara jauh. Saudara dekat menurut orang jawa adalah saudara kandung ayah, ibu serta anakanak mereka, selain dari pada mereka, disebut dengan saudara jauh. ${ }^{27}$ Pada pemaparan pengarang kitab akhlakul lilbanin menjelaskan tentang kewajiban kita untuk berakhlak kepada saudara kita, baik yang dekat dan jauh. Akhlak yang kita lakukan di antaranya yaitu :

a. Menghormati saudaramu yang lebih tua, baik laki-laki atau perempuan.

b. Mencintai mereka, dengan sebenar-benarnya.

c. Mengikuti nasehat-nasehat mereka.

d. Menghormati saudara-saudaramu yang masih kecil.

\footnotetext{
${ }^{26}$ Umar Bin Achmad Baradja, Bimbingan Akhlak Jilid 2, ...19.

${ }^{27}$ Departemen Pendidikan dan Kebudayaan. Dampak Moderenisasi Terhadap Hubungan Kekerabatan di Daerah Jawa Tengah (Jawa Tengah: Departemen Pendidikan), 67.
} 
e. Mencintai mereka dengan sebenar-benar cinta, sebagaimana cintamu kepada saudara-saudaramu yang lebih tua.

f. Tidak memusuhi mereka dengan memukul atau berkata kotor.

g. Tidak menyakiti mereka.

h. Tidak menyembunyikan mainan mereka, karena hal itu bisa memancing kemarahan kedua orang tua.

i. Tidak bertengkar kepada mereka, ketika akan masuk kamar mandi,

j. bermain, duduk atau apapun itu.

k. Selalu sabar menghadapi mereka semua. ${ }^{28}$

\section{Akhlak Kepada Para Guru}

Guru adalah seorang yang memiliki kemampuan dan pengalaman yang dapat memudahkan dalam melaksanakan peranannya membimbing muridnya. Guru harus sanggup menilai diri sendiri tanpa berlebih-lebihan, sanggup berkomunikasi dan bekerja bersama orang lain selain itu perlu di perhatikan pula dalam hal mana ia memiliki kemampuan dan kelemahan. ${ }^{29}$ Keberadaan Guru adalah salah satu komponen menusiawi dalam proses belajar mengajar, yang ikut berperan dalam usaha pembentukan sumber daya manusia yang potensial. Oleh karena itu guru yang merupakan salah satu unsur di bidang pendidikan harus berperan serta secara aktif dan menempatkan kedudukanya sebagai tenaga profesional, sesuai dengan ketentuan masyarakat yang berkembang. Dalam arti membawa para siswanya pada suatu kedewasaan atau taraf kematangan tertentu. ${ }^{30}$

Berdasarkan pemaparan di atas terlihat peran penting dari seorang guru, maka seharusnya seorang murid atau anak, menghormati dan berkahlak yang mulia kepadanya, Umar Ibnu Ahmad Barjah memaparkan dalam kitabnya akhlakul lil banin juz 1, tentang cara berakhlak kepada guru, yaitu:

a. Duduk di depannya dengan penuh sopan santun.

b. Berbicara dengan sopan.

c. Ketika beliau berbicara, jangan memotong pembicaraannya, tetapi tunggulah sampai selesai bicara.

d. Dengarkan dan perhatikanlah apa yang disampaikan dalam materi pelajaran.

e. Jika kamu tidak paham, bertanyalah dengan sopan dan halus.

${ }^{28}$ Khoirul Zad Findy, Akhlakul lil Bani Jilid 1: Umar Ibnu Ahmad Barjah inilah akhlak yang mulia,....37-38.

${ }^{29}$ Zakiah Dradjat, Metodologi pengajaran agama Islam, (Jakarta: PT.Ikrar Mandiriabadi, 2001), 266.

${ }^{30}$ Sardiman A.M, Interaksi Dan Motivasi Belajar Mengajar, Jakarta: PT. RajaGrafindo Persada, 2004), 125. 
f. Mengangkat tangan terlebih dahulu, sampai di izinkan untuk bertanya.

g. Jika ditanya, maka berdirilah dan jawab pertanyaannya dengan baik.

h. Jangan menjawab pertanyaan yang diajukan kepada orang lain, karena itu tidak beradab. ${ }^{31}$

Sayyidina Ali bin Abi Thalib dalam Abudinnata menjelaskan, tentang akhlah seorang murid kepada guru, yaitu, seorang murid wajib menghormati dan memuliakan guru, jangan mencela orang di depannya, jangan membuka rahasia, jika guru salah sebaiknya secepatnya di maafkan, seorang murid jangan pula duduk didepan guru, jika guru butuh bantuan maka berlomba-lombalah untuk membantunya, selama guru tidak melanggar larangan Allah SWT atau melalaikan perintah-Nya. ${ }^{32}$ Perhatian yang sangat lebih dari Umar Ibnu Ahmad Barjah dalam pendidikan akhlak terutama akhlak untuk mendapatkan ilmu pengetahuan. Dalam Hadits: "sesungguhnya manusia yang paling keras siksannya di hari kiamat adalah orang alim yang tidak diberi manfaat oleh Allah dengan ilmunya." Pemimpin Mesir, Sa'ad Zaghul Pasya berkata, "kami tidak membutuhkan banyak ilmu, tetapi kami membutuhkan banyak akhlak yang mulia". ${ }^{33}$

\section{Penutup}

Berdasarkan uraian atas dapat disimpulkan bahwa Umar Ibnu Ahmad Barjah menjelaskan tentang, penanaman akhlak kepada seorang anak pada usia dini sangatlah penting, karena akar dari akhlak yang mulia di waktu dewasa berawal pada pemberian sejak kecil. Jadi jalan menjadi pribadi dengan akhlak mulia harus di tanamkan sejak kecil. Umar Ibnu Ahmad Barjah mencontohkan tentang keberadaan ranting yang bengkok namun pohon sudah terlanjur besar dan rantingnya sudah tebal. Begitulah sebuah contoh dari seorang anak yang tidak berakhlak dari kecilnya, tidak mungkin ia berakhlak dikala dia telah besar. Dalam konteks pendidikan akhlak, harus ditempuh secara runtut dari mulai, pemberian pendidikan akhlak kepada Allah SWT adalah segala prilaku yang dilakukan oleh seseorang yang ditujukan kepada Allah SWT, Akhlak kepada Nabi Muhammad SAW, Akhlak kepada kedua orang tua, Akhlak kepada saudara, Akhlak kepada tetangga dan Akhlak kepada guru.

\footnotetext{
${ }^{31}$ Khoirul Zad Findy, Akhlakul lil Bani Jilid 1: Umar Ibnu Ahmad Barjah inilah akhlak yang mulia, ....54-56.

${ }^{32}$ Abuddin Nata, Filsafat Pendidikan Islam, Jakarta: Gaya Media Pratama, 2005), 135.

${ }^{33}$ Umar Bin Achmad Baradja, Bimbingan Akhlak Jilid 3 (Jakarta: Pustaka Amani, 1337 $\mathrm{H} / 2016), 4$.
} 


\section{Daftar Pustaka}

A.M, Sardiman. Interaksi Dan Motivasi Belajar Mengajar. Jakarta: PT. RajaGrafindo Persada, 2004.

Abdul Halim, Ali. Ma'a al-Aqidah wa al-harakah wa al-manhaj fi Khairi Ummatin Ukhrijat li An-Nas. Jakarta: Gema Insan Press, 1992.

Abdul Wahab, Muhbib. Selalu Ada Jawaban. Jakarta Selatan: Agromedia Pustaka, 2013.

Achmad Asseggaf, Muhammad. Sekelumit riwayat hidup Al-Ustadz Umar bin Achmad Baradja. Surabaya: Panitia Haul ke-V, 1995.

Afifuddin, Afifuddin dan Beni Ahmad Saebani. Metodologi Penelitian Kualitatif. Bandung:Pustaka Setia, 2009.

Arifin, M. Ilmu Pendidikan Islam Suatu Tinjauan Teoritis dan Praktis Berdasarkan Pendidikan Interdisipliner. Jakarta: PT. Bumi Aksara, 1991.

Bin Achmad Baradja, Umar. Bimbingan Akhlak Jilid 2. Jakarta: Pustaka Amani, $1337 \mathrm{H}$.

Bin Achmad Baradja, Umar. Bimbingan Akhlak Jilid 3. Jakarta: Pustaka Amani, $1337 \mathrm{H}$.

Departemen Pendidikan dan Kebudayaan. Dampak Moderenisasi Terhadap Hubungan Kekerabatan di Daerah Jawa Tengah. Jawa Tengah: Departemen Pendidikan.

Dradjat, Zakiah. Metodologi pengajaran agama Islam. Jakarta: PT.Ikrar Mandiriabadi, 2001.

Hasan Haris Baharits, Adnan. Mendidik Anak Laki-laki. Jakarta: Gema Insani, 2007.

Hasan Haris Baharits, Adnan. Tangung Jawab Anak Terhadap Anak. Jakarta: Gema Insani, 1996.

Lajih, Rod. Dalam Buaian Nabi Merajut Kebahagiaan Si Kecil. Jakarta: Zahra, 2005.

Majalah Al Kisah No. 07/Tahun V/26 Maret, 8 April 2007.

Muhammad Kholil As-Syafi'I, Ali. Iltizam Membangun Komitmen Seorang Muslim. Jakarta: Gema Insani Press, 2003.

Nata, Abudin. Filsafat Pendidikan Islam. Jakarta: Gaya Media Pratama, 2005.

Neolaka dan Grace Amialia, Amos. Landasan Pendidikan Dasar Diri Sendiri Menuju Perubahan Hidup. Depok: Kencana, 2017.

Pascasarjana Uin Sunan Ampel. Antologi Kajian Islam, Seri 27. Surabaya: PASCA UINSA, 2016.

Sugino, Sugino, dkk. Pengantar Ilmu Pendidikan. Surabaya: Penerbit Bintang, 2010.

Sultani, Sultani dan Ghulam. Hal yang bersih kunci ketenangan Jiwa. Jakarta: Zahra Publising, 2006.

Sultoni Dalimunthe, Sehat. Filsafat Pendidikan Islam Sebuah Bangunan Islamic Stadies. Yogyakarta: Budi Utama, 2018

Tardib. "Pendidikan Karakter dalam Islam Pemikiran Imam Al-Ghazali tentang Pendidikan Karakter Anak Berbasis Akhlak al-karimah, Vol 03. No.02 Desember, 2017.

Tim Dosen KTP IKIP Malang, Pengantar Pendidikan, Departemen Pendidikan dan Kebudayaan IKIP Malang: Malang.

W.Drisco and Dina Marschi, James. Content Analysis New York: Oxford, 2016.

Yayasan Jati Diri Bangsa, Membangun Kembali Jati Diri Bangsa, tt: Jati Diri Bangsa. 
$\underline{\text { Tajdid: Jurnal Pemikiran Keislaman dan Kemanusiaan }}$

Vol. 2 No. 2 Oktober 2018

Zad Findy, Khoirul. Terjemah. Akhlakul lil Bani Jilid 1: Umar Ibnu Ahmad Barjah (inilah akhlak yang mulia) Jakarta: Alfindy Press.

Zed, Mestika. Metode Penelitian Kepustakaan. Jakarta: Yayasan Obor Indonesia, 2008. 